\title{
28. PHYSICAL PROPERTIES OF SEDIMENT FROM THE LESSER ANTILLES MARGIN ALONG THE BARBADOS RIDGE: RESULTS FROM DEEP SEA DRILLING PROJECT LEG 78A ${ }^{1}$
}

\author{
Michael S. Marlow and Homa J. Lee, U.S. Geological Survey \\ and \\ Audrey W. Wright, Scripps Institution of Oceanography ${ }^{2}$
}

\begin{abstract}
Sediment cored within the Barbados subduction complex at Sites 541 and 542 are underconsolidated. Underconsolidation and changes in physical properties of the cored section can be related to excess pore water pressure that equals the lithostatic load at Site 542 and to major thrust faulting observed at Site 541. Apparently, the pore fluids within the subduction complex are absorbing the tectonic shock of underthrusting. Sediment sampled from the reference Site 543 on the adjacent Atlantic Plate are also underconsolidated. However, underconsolidation in Hole 543 is apparently due to the movement of excess nitrogen gas observed deeper in the hole. Excess gas was not observed at Sites 541 and 542.
\end{abstract}

\section{INTRODUCTION}

Physical properties of sediment from the Lesser Antilles margin were measured to determine the effects in these deposits of vertical consolidation and subduction beneath the margin. Prior studies indicate that subduction along convergent margins results in tectonic stress and elevated pore water pressures within sediment beneath the landward trench slope, which in turn effects the physical properties of sediment within the deformation complex (Lee et al., 1973; Bouma and Moore, 1975; Carson, 1977; Carson and Bruns, 1980; Carson et al., 1982; von Huene and Lee, 1983). The Lesser Antilles convergent margin is an area where the effects on sediment of both subduction and offscraping can be observed within a zone of relatively slow convergence of 1 to $2 \mathrm{~cm} / \mathrm{y}$. between the Atlantic and Caribbean plates.

Sites 541 and 542 are located on the toe of the landward trench slope (Fig. 1), where elevated pore water pressures and subhorizontal tectonic forces induced by convergence are expected to modify the normal effects of vertical consolidation. Site 543, on the other hand, is located to the east on the Atlantic Plate (Fig. 1) where the sedimentary section should be dominated by normal vertical compaction.

On-board we measured the recovered cores for sonic velocity, wet bulk density, porosity, water content (percent wet weight), vane shear strength, and thermal conductivity. Logging was not available on this leg. The results are tabulated in each site report in this volume. Onshore laboratory studies included low pressure consolidation tests on selected cores from each site, and the results are discussed later in this chapter.

In this chapter, we discuss the physical property data in sequence by site, from west to east. In the final sec-

\footnotetext{
${ }^{1}$ Biju-Duval, B., Moore, J. C., et al., Init. Repts. DSDP, 78A: Washington (U.S. Govt. Printing Office).

2 Addresses: (Marlow and Lee) U.S. Geological Survey, 345 Middlefield Rd., Menlo Park, CA; (Wright) Deep Sea Drilling Project, Mail Code A-031, Scripps Institution of Oceanography, La Jolla, CA 92093.
}

tion we consider effects of tectonic deformation due to subduction on the physical properties of strata within the subduction complex under the landward trench slope.

\section{RESULTS}

\section{Sites 541 and 542, Landward Slope of the Trench}

These sites are located along the toe of the landward trench slope within the subduction complex. Site 541, in a water depth of $4940 \mathrm{~m}$, is further up the trench slope than Site 542. The lithologies at Sites 541 and 542 are nearly identical, except that drilling at 541 penetrated a radiolarian mudstone of the lower Miocene, which was not reached at Site 542 (Figs. 2 and 3). The lithology of the two holes consists of (1) Quaternary and Pliocene calcareous sediment, which is composed of marly nannofossil ooze, marly foraminifer ooze, and nannofossil mud; (2) hemipelagic, locally ashy, smectitic mud, barren of calcareous detritus, which ranges from lower Pliocene or uppermost Miocene to the boundary between middle and lower Miocene; and (3) upper lower Miocene radiolarian mudstone (at Site 541 only).

The physical properties of the sections in each hole reflect the changes in downhole lithology. The compressional velocity downhole at Sites 541 and 542 is extremely uniform and the variation is quite small (Figs. 2 and 3 ). For instance, the slowest velocity at Site 541 is $1.48 \mathrm{~km} / \mathrm{s}$ at a sub-bottom depth of $7.5 \mathrm{~m}$, whereas the fastest velocity is $1.73 \mathrm{~km} / \mathrm{s}$ at $305 \mathrm{~m}$ sub-bottom, which is a difference in velocity of only $16.5 \%$. Likewise, at Site 542 , the fastest and slowest velocities are 1.55 and $1.64 \mathrm{~km} / \mathrm{s}$, respectively, which is a difference of only $6 \%$. The drilled section in each hole is acoustically isotropic (see site reports), except for the interval from $438 \mathrm{~m}$ to the bottom at Site 541, where the bit encountered a radiolarianbearing, yellowish brown upper lower Miocene mudstone (Lithology 3, just described). There is a slight increase in density and decrease in porosity and water content associated with this lithologic change (Fig. 2). This lithologic change also corresponds to a major reflection 


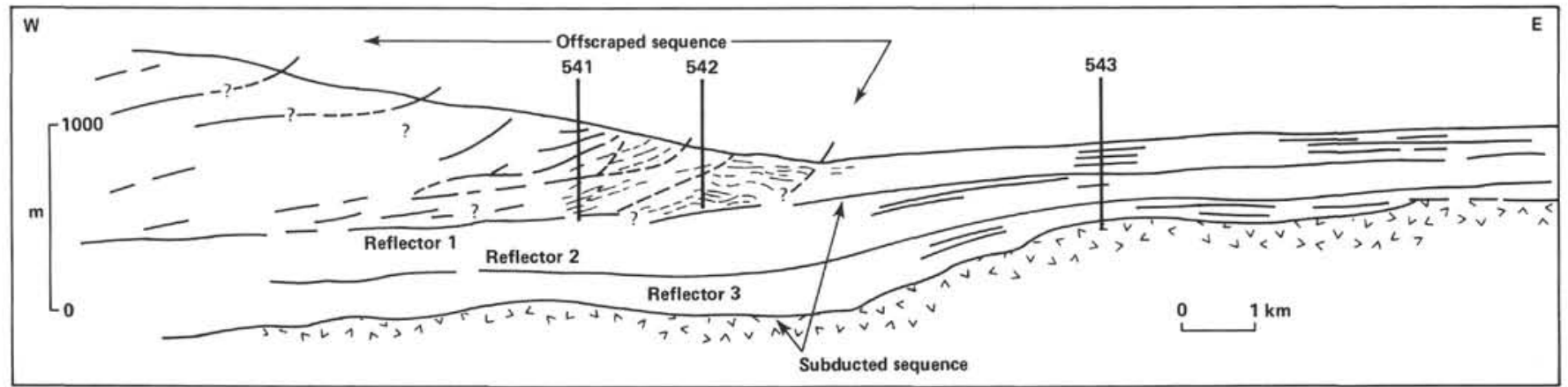

Figure 1. Schematic profile of the toe of the Barbados Ridge, adapted from profile records. Sections penetrated at Sites 541-543 are indicated by vertical lines. Site 543, the oceanic reference site, is seaward of the offscraped toe of the Ridge, but is also north of Sites 541 and 542, separated from them by a portion of the Tiburon Rise, not shown.

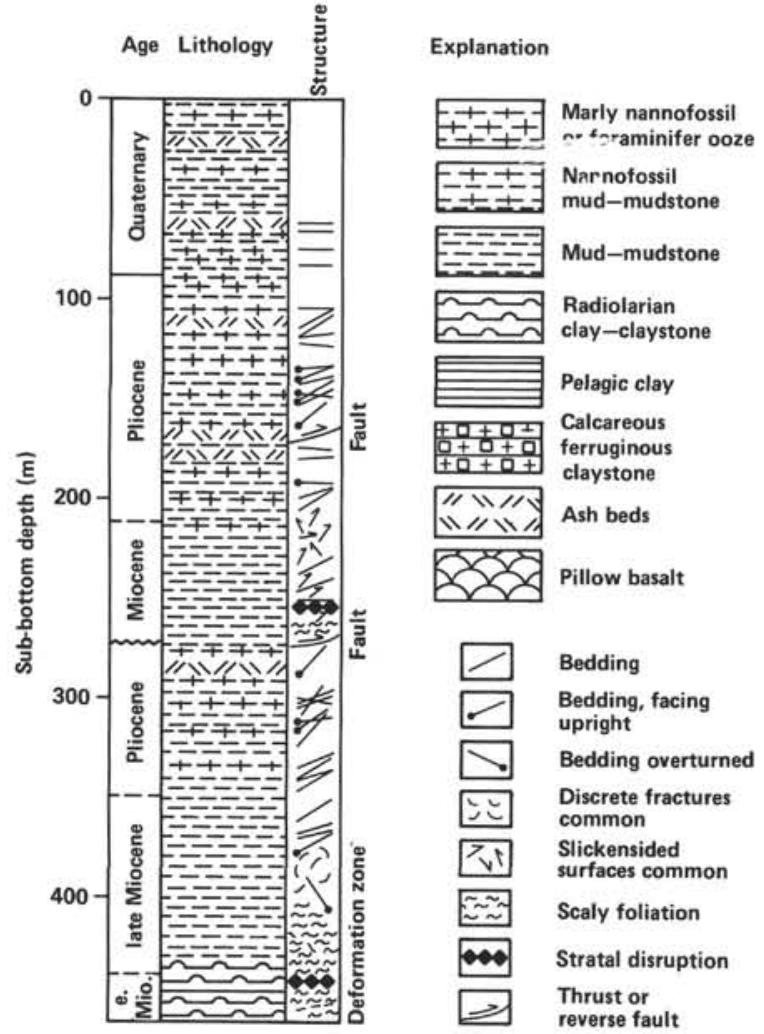

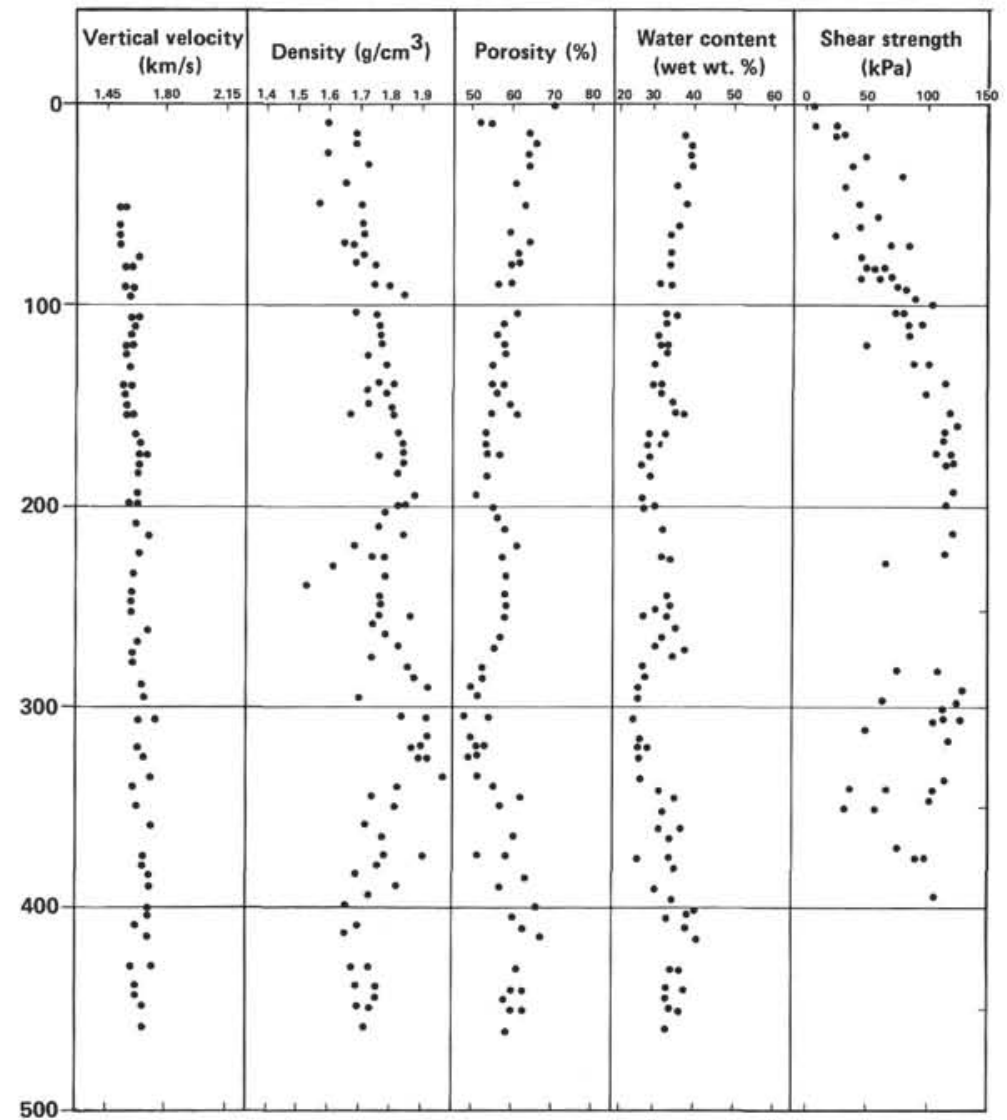

Figure 2. Plots of lithology, structure, vertical velocity, density, porosity, water content, and vane shear versus depth as measured from core samples from Site 541 .

recorded on seismic-reflection Line A1D across the drilling site (see Biju-Duval et al., this volume).

At Site 541 the density of the drilled section increases gradually to a depth of about $200 \mathrm{~m}$, where the density drops from 1.80 to $1.70 \mathrm{~g} / \mathrm{cm}^{3}$ (Fig. 2). Between 260 and $330 \mathrm{~m}$ the density increases to about 1.90 and then decreases down to the bottom of the hole. There are corresponding changes in the porosity and water content. Near here the bit crossed a major thrust fault, which may explain the change in physical properties down the stratigraphically repeated section. The density of the section at Site 542 increases gradually to a depth of $240 \mathrm{~m}$, where the density decreases slightly and averages about $1.75 \mathrm{~g} /$ $\mathrm{cm}^{3}$ to the total drilled depth (Fig. 3).

Porosity and water content at Site 541 exhibit sinusoidal variations below $200 \mathrm{~m}$ sub-bottom similar to the variations in density; the variations have a wavelength of about 120 to $140 \mathrm{~m}$ (Fig. 2). These periodic changes may correspond to the stratigraphic repetition of Pliocene and Miocene sedimentary sequences across a major thrust fault some $270 \mathrm{~m}$ below the seafloor. The water content and porosity of the strata in Hole 542 decrease slightly to a 

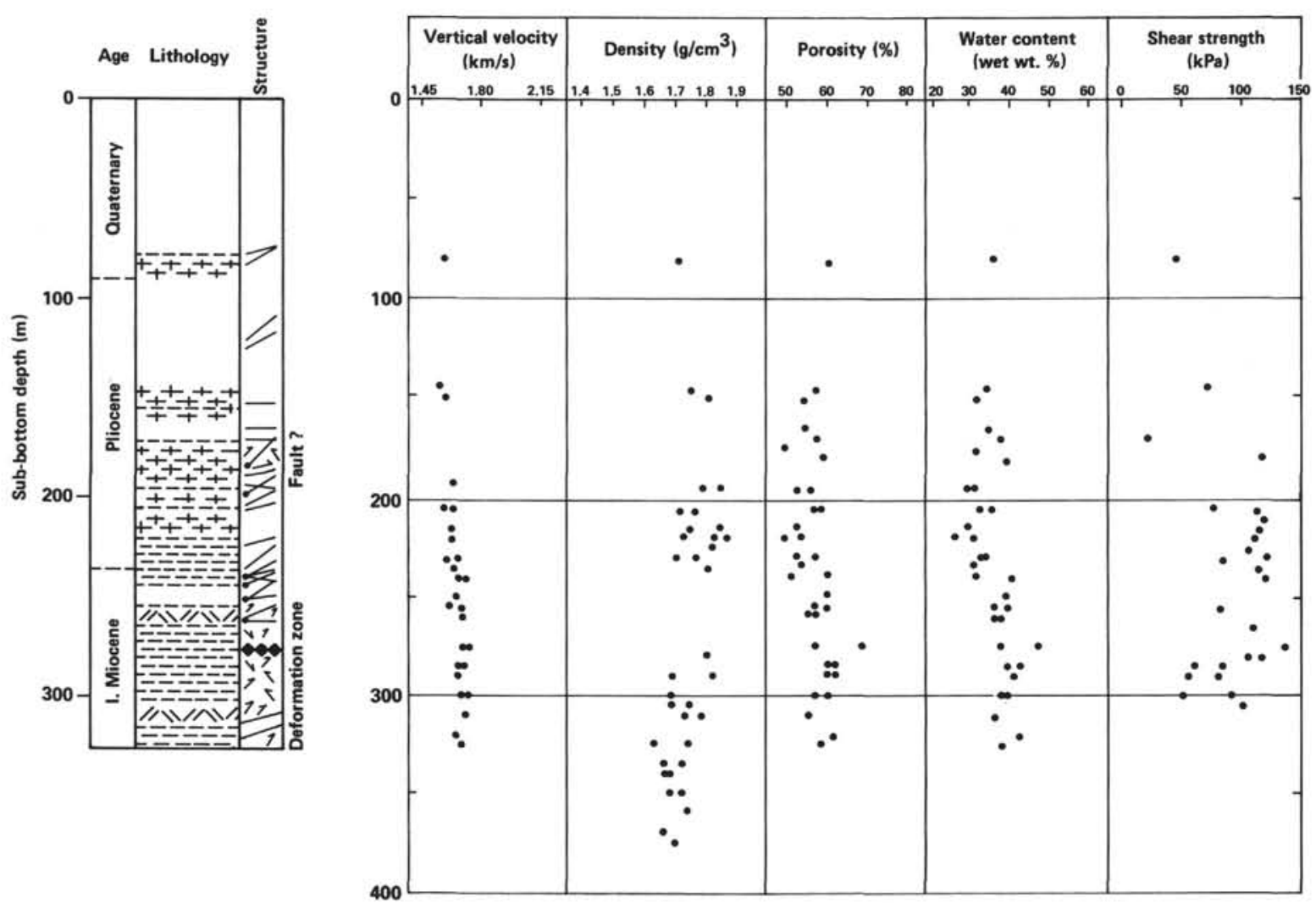

Figure 3. Plots of lithology, vertical velocity, density, porosity, water content, and vane shear versus depth as measured from core samples from Site 542. (See Fig. 2 for legend.)

depth of $250 \mathrm{~m}$ and then increase gradually with depth in deference to most situations where water content decreases with depth (Fig. 3). The unusual increase may be related to elevated pore water pressure encountered at the bottom of this hole.

The shear strength of sediment cored at Site 541 increases rapidly from the seafloor to a sub-bottom depth of $140 \mathrm{~m}$ (Fig. 2). From 140 to $270 \mathrm{~m}$ the shear strength of the section is either constant or decreases slightly. The shear strength values are generally low across a major thrust fault encountered at a depth of $276 \mathrm{~m}$. Shear strength values measured at nearby Site 542 are generally the same as the values measured at Hole 541 for the equivalent depth section (Fig. 3).

A total of 14 thermal conductivity measurements at Site 541 generally indicate that where the sedimentary section is porous and has a high water content, the thermal conductivity is generally low, around 2 to $3 \mathrm{mcal} /$ $(\mathrm{cm} \cdot \mathrm{g} \cdot \mathrm{s})$. Likewise, all four thermal conductivity measurements at Site 542 are generally low, around 3 $\mathrm{mcal} /(\mathrm{cm} \cdot \mathrm{g} \cdot \mathrm{s})$.

\section{Site 543, Seaward Slope of the Trench}

Site 543 was drilled on the seaward slope of the trench in a water depth of $5633 \mathrm{~m}$. The general lithology of Site 543 from top to bottom consists of (Fig. 4): (1) Quaternary and Pliocene calcareous sediment, which is composed of marly nannofossil ooze, marly foraminifer ooze, and nannofossil mud; (2) hemipelagic, locally ashy, smectitic mud, barren of calcareous detritus, which ranges from lower Pliocene or uppermost Miocene to the boundary between middle and lower Miocene; (3) radiolarian clay-claystone ranging from lower Miocene to Eocene; (4) pelagic, zeolitic clay and claystone ranging from Eocene to Upper Cretaceous; (5) a basal calcareous, ferruginous claystone containing Upper Cretaceous (Maestrichtian to Campanian) palygorskite and dolomite; and (6) plagioclase and plagioclase-olivine phyric pillow basalts that extend to a total depth of $455 \mathrm{~m}$.

The variation in compressional velocity downhole at Site 543 is gradual and small except for a few scattered points and significantly higher velocities in oceanic crust basalts at the bottom of the hole (see Site 543 report). The sedimentary section at Site 543 is isotropic above $300 \mathrm{~m}$ sub-bottom; the sedimentary section below $300 \mathrm{~m}$ is anisotropic, which may reflect the change in lithology from radiolarian clay to pelagic clay at $300 \mathrm{~m}$.

The density of the upper $90 \mathrm{~m}$ of strata increases gradually from 1.5 to $1.65 \mathrm{~g} / \mathrm{cm}^{3}$ (Fig. 4). Below $90 \mathrm{~m}$ the density decreases abruptly to about $1.45 \mathrm{~g} / \mathrm{cm}^{3}$. Below $210 \mathrm{~m}$ the density of sediment increases dramatically to about $1.75 \mathrm{~g} / \mathrm{cm}^{3}$, reflecting the lithologic transition from ashy mudstone to more consolidated radiolarian clay. Porosity and water content vary in an inverse relation to density in the upper $200 \mathrm{~m}$ of the hole, often by $20 \%$ over a span of just a few tens of meters in the hole. Both po- 


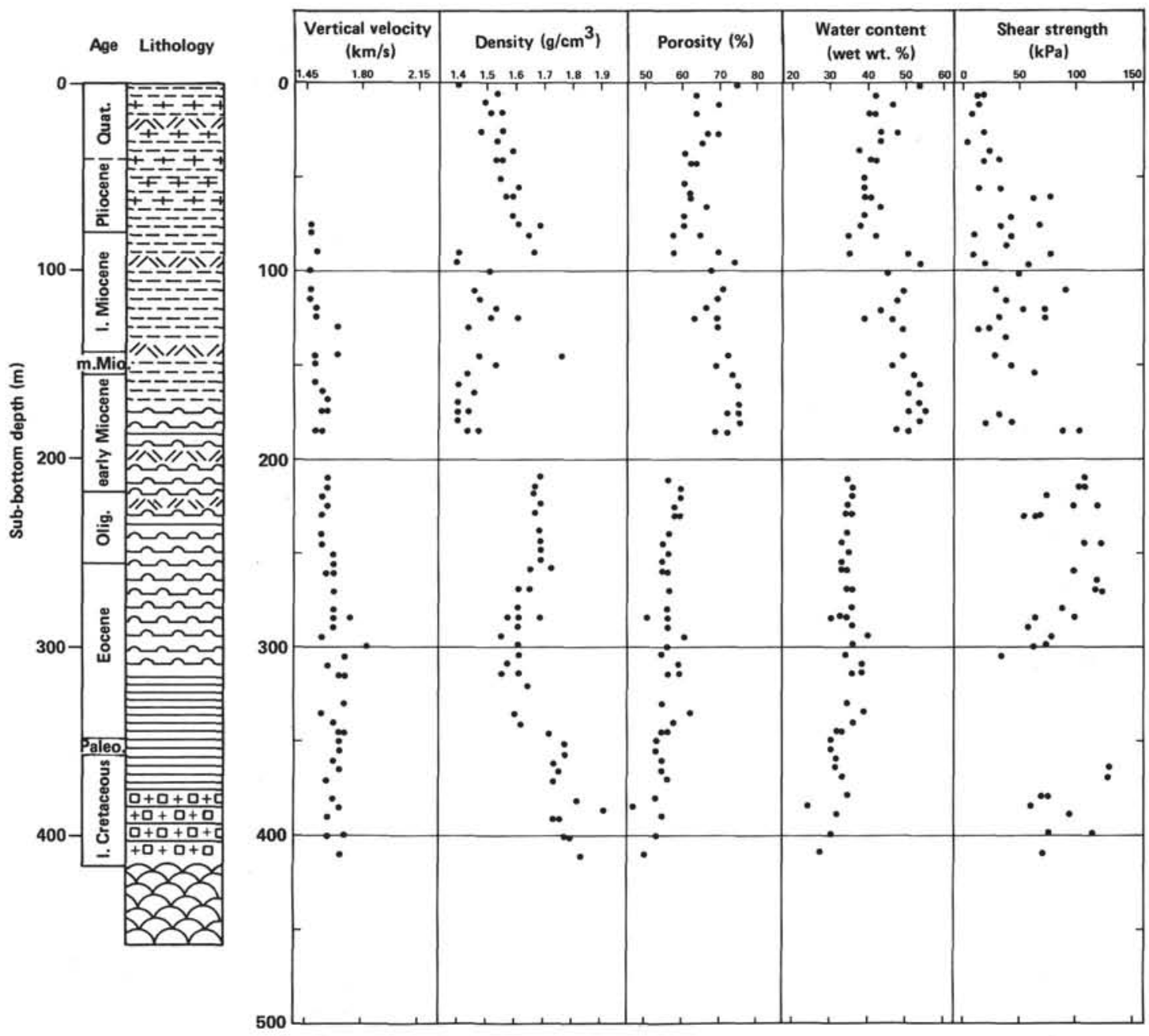

Figure 4. Plot of lithology, vertical velocity, density, porosity, water content, and vane shear versus depth as measured from core samples from Site 543. (See Fig. 2 for legend.)

rosity and water content decrease gradually below 200 $\mathrm{m}$, presumably from overburden pressure, age, and compaction.

The shear strength of the section drilled at Site 543 is more variable than the equivalent sections at Sites 541 and 542 (Figs. 2-4). At the latter two sites, shear strength increases downhole to $200 \mathrm{~m}$ in a more linear fashion, in contrast to the scattered shear strength values at Site 543.

A total of eight measurements of thermal conductivity at Site 543 revealed that values here are about $10 \%$ lower than readings made at the other two sites, averaging about $2.5 \mathrm{mcal} /(\mathrm{cm} \cdot \mathrm{g} \cdot \mathrm{s})$. One high value of $3.5 \mathrm{mcal} /(\mathrm{cm} \cdot \mathrm{g} \cdot \mathrm{s})$ was measured near the bottom of Hole 543.

\section{SHORE LABORATORY TESTS}

\section{Consolidation}

The conditions of the one-dimensional consolidation test, which involve monitoring the compression of a wafer of sediment as it is subjected to incrementally increasing vertical loads, in many ways model the process of sedimentation. A critical parameter, the maximum past vertical stress, $\sigma_{v m}^{\prime}$, can be estimated by observing the stress level at which the rate of compression increases rapidly. Casagrande (1936) presented a consistent method for obtaining an estimate of the maximum past stress from a consolidation test. Once the maximum past stress is known, the consolidation state of a sedimentary deposit can be assessed. The present in situ vertical effective overburden, $\sigma_{0}^{\prime}$, corresponding to the sample depth, is calculated by integrating the submerged density, $\gamma_{b}$, with respect to depth over the range of depths above the sample:

$$
\sigma_{0}^{\prime}=\int_{0}^{z_{0}} \gamma_{b}(z) d x
$$

where $\gamma_{b}(z)=$ submerged density as a function of $x, z$ $=$ variable depth above sample, and $z_{0}=$ depth of sample.

For relatively uniform deposits, $\sigma_{0}^{\prime}$ is equal to the average value of $\gamma_{b}$ times $z_{0}$. If the maximum past stress, $\sigma_{v m}^{\prime}$, is greater than $\sigma_{0}^{\prime}$, the sediment is overconsolidated: it has experienced greater stresses in the past than it is presently experiencing. If $\sigma_{v m}^{\prime}$ equals $\sigma_{0}^{\prime}$, the sediment is normally consolidated: it is in equilibrium with its present overburden and has not experienced any greater loads in 
the past. If $\sigma_{v m}^{\prime}$ is less than $\sigma_{0}^{\prime}$, the sediment is not in equilibrium with its present overburden and is said to be underconsolidated. Underconsolidation may occur if some of the overburden pressure is carried by elevated pore water pressures and the in situ vertical effective or intergranular stress, $\sigma_{v}^{\prime}$, is equal to $\sigma_{v m}^{\prime}$. The elevated pore water pressure, $u$, is equal to $\sigma_{0}^{\prime}-\sigma_{v m}^{\prime}$. For the normally or overconsolidated cases, $\sigma_{v}^{\prime}$ equals $\sigma_{0}^{\prime}$.

Six one-dimensional consolidation tests were performed on samples from Leg 78A using standard procedures (Table 1; ASTM, 1981). Samples could only be taken from upper parts of the holes because deeper samples were too consolidated for low pressure testing. The primary objective of the tests was to measure the maximum past stress and determine consolidation state. A secondary objective was to obtain the sediment parameters $C_{c}$ (compression index), $c_{v}$ (coefficient of consolidation), and $k$ (permeability).

Four of the samples tested were from Site 541, a location with a similar geologic history to that of Site 542 where elevated pore pressure measurements approached the lithostatic stress ( $u$ nearly equal to $\left.\sigma_{0}^{\prime}\right)$ in deep fractured sediment at the bottom of the hole. A significant level of underconsolidation in the overlying sediment would indicate that these high elevated pore pressures were a near steady-state situation continually affecting overlying materials.

Two of the samples tested were from Site 543, a reference station removed from the present subduction front (Table 1). We expected to measure normal consolidation at Site 543 as a result of slow pelagic sedimentation and the absence of tectonic stresses.

The results of the tests are presented in standard engineering format (void ratio versus the log of vertical effective stress) in Figures 5 and 6. The coefficient of consolidation, $c_{v}$, is also included and will be used in a later analysis. Table 1 summarizes the critical parameters obtained from each test and includes an estimate of permeability, which is obtained from consolidation test data and the theory of consolidation (Lambe, 1951).

The estimated maximum past stresses are plotted versus the calculated effective overburden in Figure 7. For Site 541 the results indicate a slight level of overconsolidation in the upper $40 \mathrm{~m}$ advancing into a consistently increasing degree of underconsolidation below $40 \mathrm{~m}$. Both tests from Site 543 indicate a degree of consolidation $\left(\sigma_{v m}^{\prime} / \sigma_{0}^{\prime}\right)$ of about $70 \%$ at 110 to $160 \mathrm{~m}$, slightly greater than the degree of consolidation at Site 541 for the same overburden but not significantly so.

Both sites were analyzed for underconsolidation resulting from rapid sedimentation using the methods of Gibson (1958). To use this method a dimensionless parameter, $m^{2} t / c_{v}$, is needed to enter a mathematical model. The parameter $m$ is the average sedimentation rate, whereas $t$ is the age of the sediment column. Using values measured for these two sites (see Wright, sedimentation rate chapter, this volume), the dimensionless parameter was determined to be 0.003 for Site 541 and 0.002 for Site 543. Because Gibson shows that dimensionless parameters in excess of about 0.1 are needed to produce a noticeable degree of underconsolidation, we conclude that the observed underconsolidation is not induced by the sedimentation rate.

At Site 541 the elevated pore pressures that produce underconsolidation may be related to subduction of sediment beneath fractured rock that attains elevated pore pressure as water migrates upward but cannot migrate freely to the seafloor. Von Huene and Lee (1983) postulated that the process of sediment subduction can lead to a different form of underconsolidation from that resulting from sedimentation alone. As the sediment is brought beneath the subduction front, it is subjected to a rapidly increasing stress field. Drainage paths are impeded by generally fine-grained sediment, and thus much of the stress field is probably carried by pore water pressures. This high pore pressure, low-strength zone would provide a plane of weakness that would continue to facilitate further sediment subduction. The pore pressures from this zone will gradually drain through the overlying rock and younger sediment such as that sampled at Site 541 . If pore water is continually subducted, the overlying sediment would never be able to achieve normal consolidation. A portion of the overburden pressure would always be supported by pore pressures developed from restrained sediment drainage.

A rough model of the expected pore pressure distribution in the sediment column can be obtained if the permeability distribution is known. Darcy's law states simply that:

$$
q=k i
$$

Table 1. Consolidation test results.

\begin{tabular}{|c|c|c|c|c|c|c|c|c|c|}
\hline Section & $\begin{array}{l}\text { Sub-bottom } \\
\text { depth } \\
\text { (m) }\end{array}$ & $\begin{array}{c}\text { Effective } \\
\text { over- } \\
\text { burden, } \\
\sigma_{0}^{\prime} \\
(\mathrm{kPa})\end{array}$ & $\begin{array}{c}\text { Maximum } \\
\text { past } \\
\text { stress, } \\
\sigma_{y m}^{\prime} \\
(\mathrm{kPa})\end{array}$ & $\begin{array}{c}\text { Degree of } \\
\text { consolidation, } \\
\sigma_{v m}^{\prime} / \sigma_{0}^{\prime} \\
(\mathrm{kPa})\end{array}$ & $\begin{array}{c}\text { Coefficient of } \\
\text { consolidation, } \\
c_{y} \\
\left(\mathrm{~cm}^{2} / \mathrm{s}\right) \\
\left(\times 10^{-4}\right)\end{array}$ & $\begin{array}{c}\text { Compression } \\
\text { index, } \\
C_{c}\end{array}$ & $\begin{array}{c}\text { Permeability, } \\
k \\
(\mathrm{~cm} / \mathrm{s})\end{array}$ & Lithology & Age \\
\hline $541-3-3$ & 15 & 70 & 160 & 2.28 & $6-60$ & 0.53 & $2 \times 10^{-8}$ & Nannofossil mud & Pleistocene \\
\hline $541-7-5$ & 55 & 340 & 310 & 0.91 & $2-100$ & 0.87 & & Nannofossil mud & Pleistocene \\
\hline $541-11-3$ & 90 & 583 & 410 & 0.70 & $3-100$ & 0.52 & & Marly ooze & Pliocene \\
\hline $541-15-4$ & 129 & 880 & 520 & 0.59 & $7-100$ & 0.42 & $2 \times 10^{-9}$ & Marly ooze & Pliocene \\
\hline $543-12-4$ & 112 & 599 & 450 & 0.75 & $9-100$ & 0.90 & & Mud & late Miocene \\
\hline $543-17-5$ & 160 & 813 & 520 & 0.64 & $1-100$ & 2.24 & & Mud & early Miocene \\
\hline
\end{tabular}

Note: Permeability values correspond to effective overburden stress. 


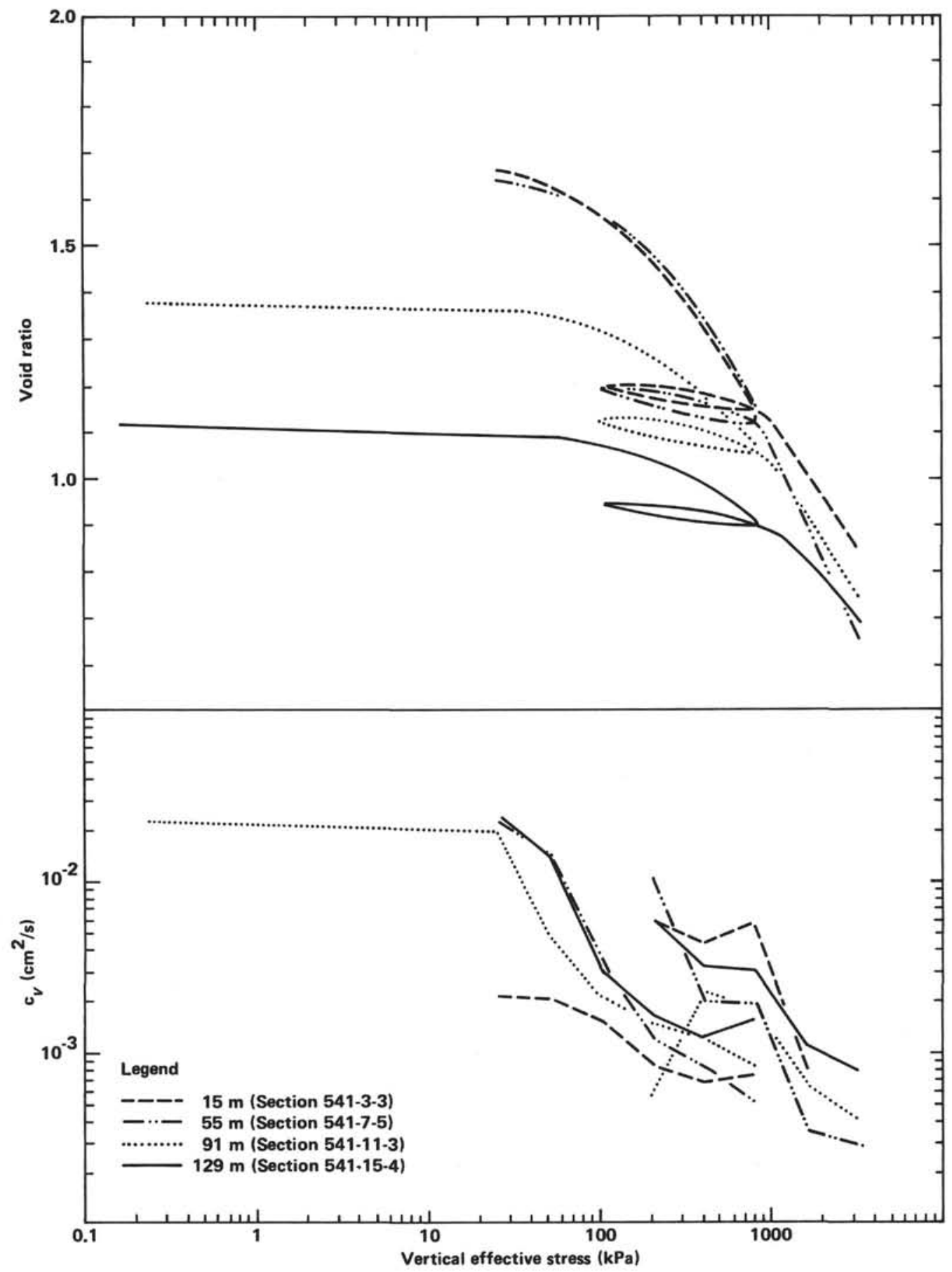

Figure 5. Consolidation test results from Site 541 on cores recovered from depths of 15, 55, 91, and $129 \mathrm{~m}$.

where $q=$ rate of upward flow per unit area, $i=$ rate of pore pressure change with depth $(d u / d z)$, and $k=$ coefficient of permeability.

Because the rate of upward flow must at any point be a constant, $i$ varies inversely with $k$. The permeability may vary by about a factor of 10 between surface sediment $(0-50 \mathrm{~m})$ and that at greater depth $(200-300 \mathrm{~m}$, Table 1). The rate of pore pressure change with depth will be much greater in the deeper sediment than in the shallow material.

From a simple model and assumed permeability, von Huene and Lee (1983) predicted a minimum of under- consolidation (1 minus the degree of consolidation) of around $30 \%$ for the subducted sediment near Barbados. Actual measurements at Site 542 showed a pore pressure of $2117 \mathrm{kPa}$ at $300 \mathrm{~m}\left(\sigma_{0}^{\prime}=2270 \mathrm{kPa}\right)$ or a degree of underconsolidation of $93 \%$. Using the higher measured value as a boundary condition for $300 \mathrm{~m}$ and a four-layer model that allows permeability to vary linearly over a factor of 10, Darcy's law may be used to predict a pore pressure distribution. Subtracting the predicted values of pore pressure from the effective overburden leads to a predicted profile of vertical effective stress, $\sigma_{v}^{\prime}$ (Fig. 7). This profile matches the measured maximum past stress- 


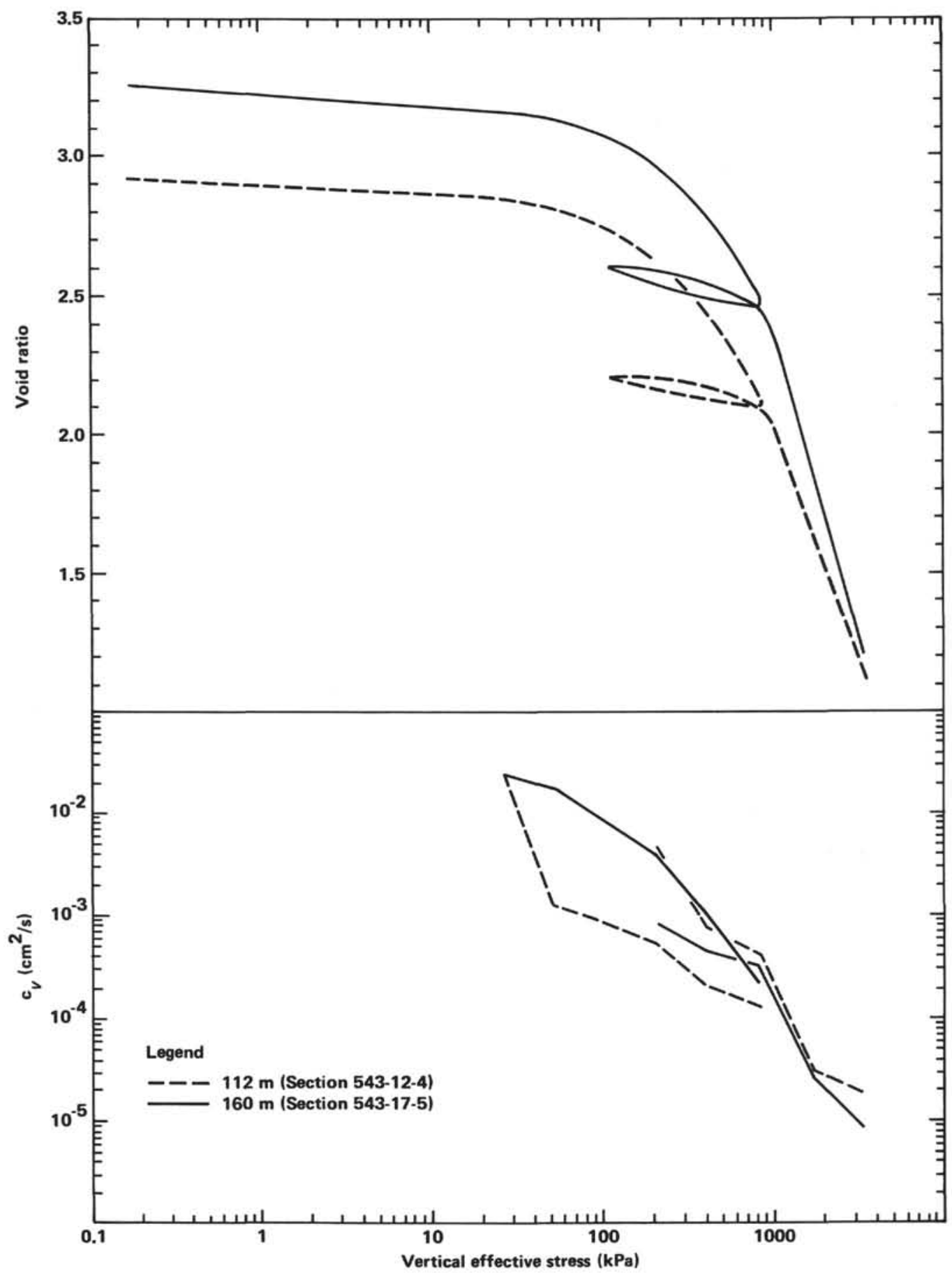

Figure 6. Consolidation test results from Site 543 on cores recovered from depths of 112 and $160 \mathrm{~m}$.

es fairly well for the lower three tests. The upper test does not match well, but this may be a result of pseudooverconsolidation, a near surface and poorly understood effect found in almost all marine sediments. The predicted profile has a maximum near $1700 \mathrm{kPa}$ of effective overburden (at about $230 \mathrm{~m}$ ) and drops sharply with greater effective overburden or depth.

\section{Triaxial Shear}

Four consolidated undrained triaxial shear tests were conducted on samples from Site 541 following the basic procedures of Bishop and Henkel (1962). The triaxial test provides a means of placing a sample under an effective stress state that is equal to or greater than that which existed in place. The sample is then failed by axial loading, and a shear strength is calculated. The triaxial test reduces the effects of sampling disturbance, because the influence of confinement is reestablished. The disturbance effects are often reduced even more through the normalized strength approach. Samples are consolidated well beyond their in situ stress state prior to shear. The measured strength at that state is then normalized by the consolidation stress. This normalized strength is assumed to apply to the true in situ effective stress, and 


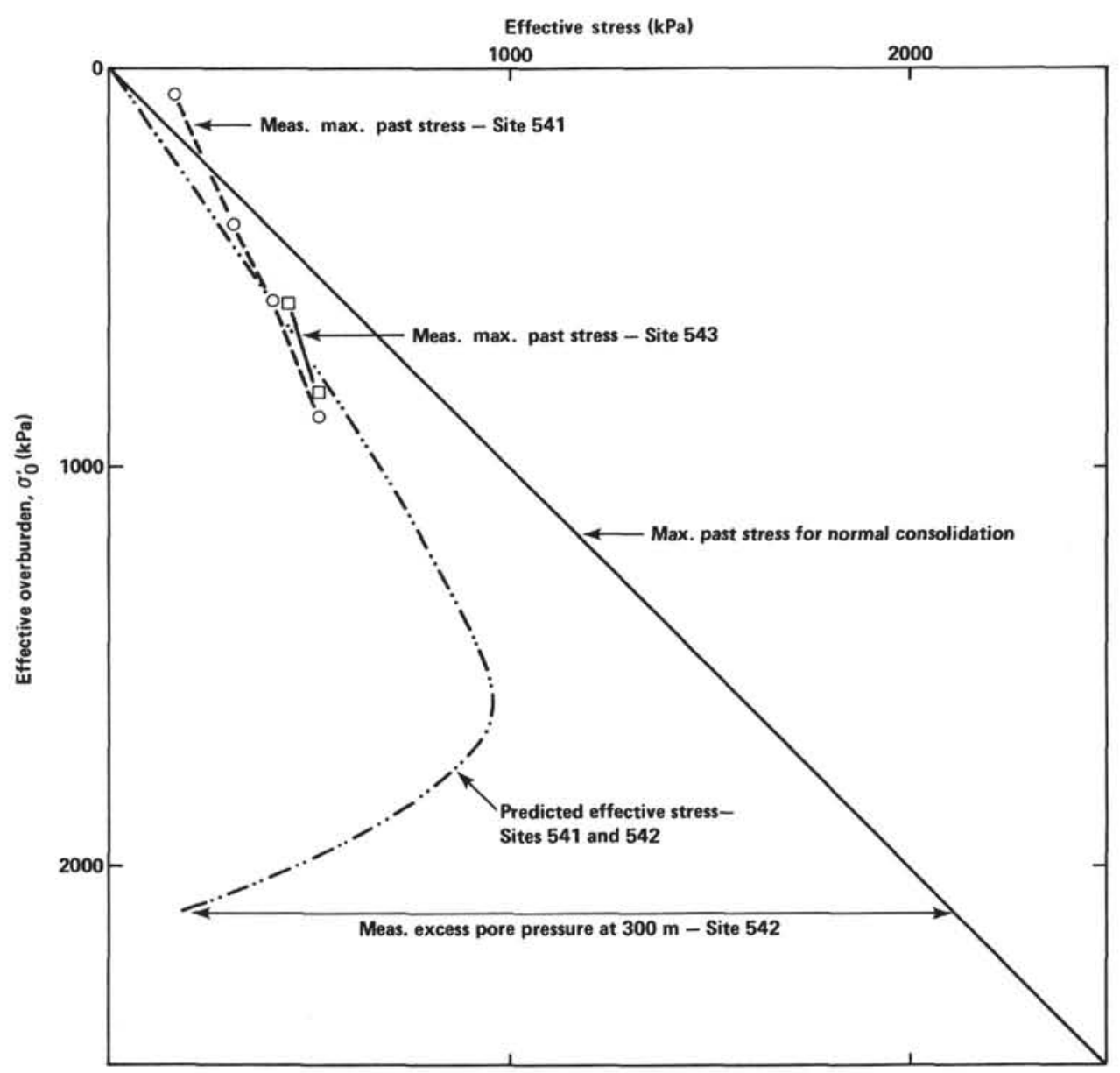

Figure 7. Measured and predicted in situ effective stresses.

a disturbance-corrected strength for the proper level is calculated (normalized strength times in situ effective stress). Ladd and Foott (1974) showed that this procedure often produces a good measure of the in-place strength.

Table 2 shows the properties measured in the four triaxial tests. Some of the samples were consolidated well beyond their in-place stress while some were not. For all tests the normalized strength was found to be nearly a constant with a mean of 0.33 . By multiplying this normalized strength value by the in situ vertical effective stress (assumed equal to the maximum past stress, determined from the consolidation tests), an estimated in situ strength profile was generated (Fig. 8).

The estimated in situ strengths exceed all of the vane shear strength measurements also shown in Figure 8. The difference can largely be attributed to disturbance, amounting to as little as $10 \%$ for a few probably good quality samples and to as much as $70 \%$ for the more disturbed sediment. Disturbance values such as these are probably roughly applicable to other DSDP sites where similar material has been cored.

\section{DISCUSSION}

One of the surprising results of Leg 78A was the uniformity of physical properties in cores from Sites 541
Table 2. Triaxial test results at Site 541 .

\begin{tabular}{|c|c|c|c|c|c|c|c|}
\hline $\begin{array}{l}\text { Core- } \\
\text { Section }\end{array}$ & $\begin{array}{l}\text { Sub-bottom } \\
\text { depth } \\
\text { (m) }\end{array}$ & $\begin{array}{c}\text { Effective } \\
\text { over- } \\
\text { burden, } \\
\sigma 0 \\
\text { (kPa) }\end{array}$ & $\begin{array}{c}\text { Maximum } \\
\text { past } \\
\text { stress, } \\
\sigma_{v m}^{\prime} \\
\text { (kPa) }\end{array}$ & $\begin{array}{c}\text { Triaxial } \\
\text { vertical } \\
\text { consolidation } \\
\text { stress, } \\
\sigma_{u c}^{\prime} \\
(\mathrm{kPa})\end{array}$ & $\begin{array}{c}\text { Triaxial } \\
\text { shear } \\
\text { strength, } \\
s_{u} \\
(\mathrm{kPa})\end{array}$ & $\begin{array}{c}\text { Normal } \\
\text { shear } \\
\text { strength } \\
S_{u} / \sigma_{v e}^{t}\end{array}$ & $\begin{array}{c}\text { Friction } \\
\text { angle } \\
\left({ }^{\circ}\right)\end{array}$ \\
\hline 3-3 & 15 & 70 & 160 & 421 & 134 & 0.318 & 25 \\
\hline 7.5 & 55 & 340 & 310 & 780 & 264 & 0.338 & 27 \\
\hline $11-3$ & 91 & 583 & 410 & 680 & 233 & 0.343 & 26 \\
\hline $15-4$ & 129 & 880 & 520 & 709 & 229 & 0.323 & 24 \\
\hline
\end{tabular}

and 542. These cores are from sections thrust within the convergence zone shown through lithologic and fossil evidence. One might expect that strata in a thrust zone would exhibit corresponding chaos in their physical properties. Yet the section drilled at these two sites is not chaotic, and changes in the physical properties of the sediment are gradual (Figs. 2 and 3).

Perhaps an explanation of the uniform nature of sediment in the subduction complex lies in the role of in si$t u$, interstitial pore fluids in the complex. These highly pressured fluids may be absorbing the tectonic "shock" of overburden pressure as well as lateral motion from the underthrusting Atlantic Plate. In a sense, highly pressured pore water may "float" the upper section such that the shearing in imbricate-stacked sediment is confined to narrow well-lubricated fault zones within the offscraped complex. Decoupling along narrow fault zones 


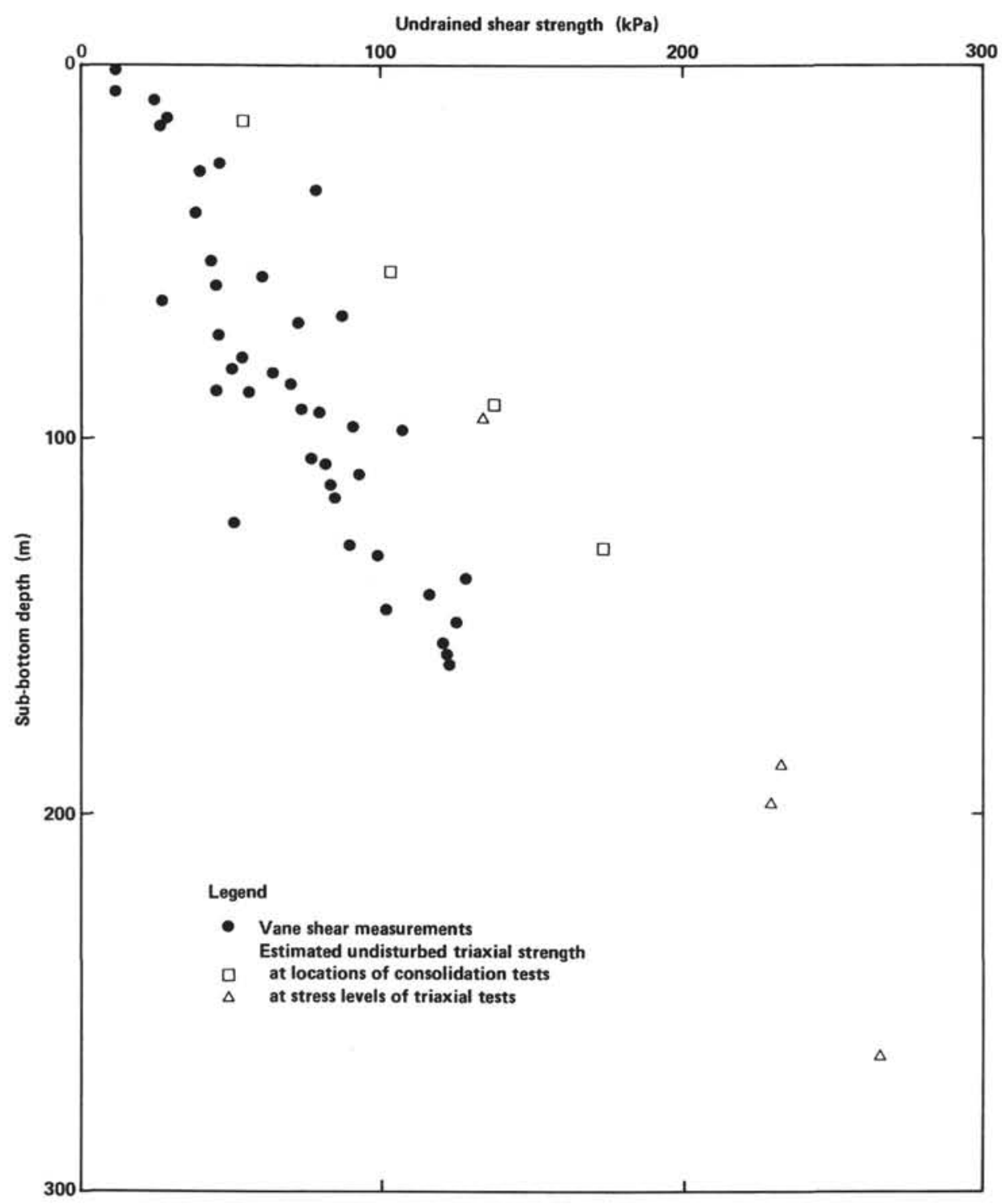

Figure 8. Undrained shear strengths from vane shear and triaxial shear testing for selected samples from Site 541 .

may also allow the strata in individual thrust packets to remain relatively undeformed with depth. Such in situ deformation may be manifested in the form of fracture porosity, which would be impossible to measure on small shipboard samples.

The predicted effective stress profile in Figure 7 may provide a mechanism for generating the fractured rock often found in subduction zones. The sediment gradually consolidates and becomes increasingly brittle in a nearly normal manner. At a critical depth pore pressure begins to increase very rapidly. The elevated pore pressure causes expansion and subsequent fracturing of the brittle rock. The fracturing might be sufficient to provide a zone of least shear strength. The zone of fractured rock could be localized or exist over a broad front, depending upon the specific stress field and mechanical properties of the rock. The major thrust fault of the subduction zone could shift upward, resulting in subduction erosion (von Huene and Lee, 1983).
The results from Site 543 are at first confusing. The sediment at Site 543 should not be underconsolidated as a result of either rapid sedimentation or subduction processes. The measured levels of underconsolidation could be an indicator of severe core disturbance, which might also affect the results from Site 541. Even if this were the case and the sediment at Site 541 were more consolidated than the measurements show, the basic shape of the effective stress curve in Figure 7 would not change greatly. The conclusions regarding processes occurring at Site 541 would be essentially the same.

The relatively low consolidation levels at Site 543 may be due to gas encountered deeper in the hole. The gas, which is mostly nitrogen, caused partings in the recovered cores; and according to Claypool (this volume), the gas is dissolved nitrogen produced by denitrification in the sediment, according to the overall reaction:

$$
5 \mathrm{CH}_{2} \mathrm{O}+4 \mathrm{HNO}_{3} \rightarrow 2 \mathrm{~N}_{2}+5 \mathrm{CO}_{2}+7 \mathrm{H}_{2} \mathrm{O}
$$


If the gas is migrating up the section, the subsequent disruption may explain the underconsolidation observed at Site 543 as well as the scatter in vane shear measurements from the hole. Significantly, no equivalent volumes of gas were encountered at Sites 541 or 542 .

\section{REFERENCES}

ASTM (American Society for Testing and Materials), 1981. Annual Book of Standards, Part 19, Natural Building Stones; Soil and Rock: Philadelphia (ASTM).

Bishop, A. W., and Henkel, D. J., 1962. The Measurement of Soil Properties in the Triaxial Test: London (Edward Arnold Ltd.).

Bouma, A. H., and Moore, J. C., 1975. Physical properties of deepsea sediments from the Philippine Sea and Sea of Japan. In Karig, D. E., Ingle, J. C., et al., Init. Repts. DSDP, 31: Washington (U.S. Govt. Printing Office), 535-568.

Carson, B., 1977. Tectonic modification of deep-sea sediments at the Washington-Oregon continental margin: mechanical consolidation. Mar. Geol., 24:289-307.

Carson, B., and Bruns, T. R., 1980. Physical properties of sediments from the Japan Trench margin and outer trench slope: Results from Deep Sea Drilling Project Legs 56 and 57. In Scientific Party, Init. Repts. DSDP, 56, 57, Pt. 2: Washington (U.S. Govt. Printing Office), 1187-1199.
Carson, B., von Huene, R., and Arthur, M., 1982. Small-scale deformation structures and physical properties related to convergence in Japan Trench slope sediments. Tectonics, 1:277-302.

Casagrande, A., 1936. The determination of the pre-consolidation load and its practical significance. Proc. First Int. Conf. Soil Mech. Found. Eng., Cambridge, Mass. p. 60.

Gibson, R. E., 1958. The progress of consolidation in a clay layer increasing in thickness with time. Geotechnique, 8:71-182.

Ladd, C. C., and Foott, R., 1974. New design procedure for stability of soft clays. J. Geotech. Div., ASCE, 100:763-786.

Lambe, T. W., 1951. Soil Testing for Engineers: New York (John Wiley and Sons).

Lee, H. J., Olsen, J. W., and von Huene, R., 1973. Physical properties of deformed sediments from Site 181. In Kulm, L. D., von Huene, R., et al., Init. Repts. DSDP, 18: Washington (U.S. Govt. Printing Office), 897-901.

von Huene, R., and Lee, H. J., 1983. The possible significance of pore fluid pressures in subduction zones. In Watkins, J. S., and Drake, C. L. (Eds.), Studies in Continental Marine Geology, Am. Assoc. Pet. Geol. Mem., 34:781-792.

Date of Initial Receipt: May 14, 1982

Date of Acceptance: November 10, 1982 